\title{
Composition of waste water from poultry factories and their suitability for irrigation of agricultural crops (as an example of Tashkent province, Uzbekistan)
}

\author{
Z. Artukmetov ${ }^{1, *}, B . \operatorname{Nasirov}^{1}, J$. Aliev $^{1}$, and N. Kamolova ${ }^{1}$ \\ ${ }^{1}$ Tashkent State Agrarian University, University str., 2, Tashkent province, Uzbekistan, 100140
}

\begin{abstract}
This article highlights the composition of wastewater from poultry farms and their suitability for irrigation of agricultural crops. It has been established that the chemical demand of wastewater from poultry farms is $480-850 \mathrm{mg} \mathrm{O} / 1$, which indicates a high level of contamination with organic products. Coarse and finely dispersed substances vary within 430-720 mg/l, and biochemical oxygen consumption on the fifth day (BOD5) within 0.39-0.74 $\mathrm{g} \mathrm{O}_{2} / 1$, and at the time of mass effluent emissions it reached $15-1.6 \mathrm{~g} \mathrm{O}_{2} / 1$. The titer of Escherichia coli was equal to $10-6$, the number of microbes ranged from $48.5 \times 106$ to $61.6 \times 106$. Determination of the suitability of wastewater based on generally accepted methods showed that they are quite suitable for irrigation of crops without additional reclamation measures.
\end{abstract}

\section{Introduction}

Water for irrigation in the arid zone of Central Asia, including the Republic of Uzbekistan, is a necessary factor in agriculture. In the Republic of Uzbekistan, the main factor of food security is irrigated agriculture. To expand the area of irrigated agriculture, free water resources are needed, although the available water resources in the republic can expand the area of irrigated agriculture 4.8 million hectares. With the existing level of irrigation technologies, there is a strong shortage of irrigation water [1-3].

Anthropogenic water transformations in the region have already reached a global scale: the intensive development of irrigated agriculture in the second half of the 20th century led to a significant increase in water intake from the Syr Darya and Amu Darya basins, which caused the Aral Sea to become shallow $[4,11]$. At present, the volume of the sea is only $28 \%$ of the indicator in 1960 . A. Kurtov argues that the lack of water for the Republic of Uzbekistan is a disaster in the truest sense of the word: due to the lack of water in a number of regions of the republic, especially in Karakalpakia, one can already say about the social and economic crisis $[5,8]$. There is not enough water not only for agricultural purposes, but

* Corresponding author: tuag-info@edu.uz 
also for purely bit needs. If before 2000 years of low water supply in the region were observed every 6-8 years, now this phenomenon is repeated every 3-4 years. In 2018 and 2019, water availability decreased significantly [6].

The urgent problem of the current stage of economic and social development of the republic is the protection of the environment and, in particular, the elimination of the danger of the negative impact on it of the growing volume of wastewater from poultry farms. Intensively developing poultry farms and enterprises are one of the pollutants of the republic's water bodies [5]. Applied artificial treatment facilities often turn out to be ineffective, retaining only $50-60 \%$ of the ingredients in the wastewater, because the technological process of mechanical and biological treatment at wastewater treatment plants functions poorly due to their unsatisfactory operation, imperfection of the technological cleaning process itself, and they work with greater overload. Therefore, very promising from the national economic and hygienic point of view is soil disposal of wastewater and their use for irrigation of forage and grain crops, which allows increasing water availability, productivity of land and is a powerful means of increasing soil fertility, as well as an effective way of additional treatment in natural conditions [5]. In general, sewage from poultry farms in the republic can irrigate and fertilize 10-12 thousand hectares of land [7]. However, the problem of using wastewater for irrigation of crops requires a regional approach, i.e. it is necessary to take into account the peculiarities of the soil and the hydrogeological conditions of the territory $[5,10]$.

In conditions of a strong shortage of irrigation water in the Tashkent State Agrarian University, special attention is paid to conducting research work on more careful and productive use of the available water resources, including local runoff.

In the CIS republics, including the former All-Union Scientific and Production Association VNPO "Progress" (All-Union Scientific Research Institute for Agricultural Crops), Volgograd Agricultural and Ukrainian Hydro-reclamation Institutes, Uzbek Research Institute of Sanitation, Hygiene and Occupational Diseases and other institutions have carried out numerous studies to study the suitability of household and livestock wastewater for irrigation of crops. However, scientific research on the disposal of wastewater from poultry farms has been almost non-existent [5-7].

Considering all the above, the purpose of the research is to study the composition and suitability of wastewater from poultry farms for irrigation of agricultural crops in various soil and hydrogeological conditions of the republic as an effective measure to prevent pollution of water resources and save river water, determine their impact on the growth, development and productivity of cultivated crops, sanitary and hygienic condition of irrigation fields.

\section{Materials and methods}

The objects of research are waste waters of poultry farms and fodder and grain crops irrigated by them on meadow and serozem soil conditions of the Tashkent region.

The materials of the research carried out are waste waters of poultry farms in Uzbekistan and Urtachir-chikparranda, located on sierozem and meadow soils of the Tashkent region, and fodder and grain crops irrigated by them. The suitability of wastewater for irrigation of agricultural crops was determined by Budanov, Mozheiko and Vorotnik, Kelly, Eaton and Stebler, by the US Department of Defense (SAR) method [5]. 


\section{Results}

Long-term studies to determine the quality of wastewater and their suitability for use for irrigating agricultural crops have shown the following: wastewater from poultry farms is characterized by a specific (often ammoniacal) odor, cloudy color, slightly alkaline reaction of the medium ( $\mathrm{pH}=7.1-7.3)$, carbonate-sulphate, calcium-magnesium composition, according to the classification of Yu. P. Lebedev and had coarse and finely dispersed substances, which were contained in an amount of 430-720 mg/l on average, therefore, reuse wastewater in the production process or dispose of it in the opening reservoirs without thorough cleaning is unacceptable, since the concentration of most of the ingredients in them exceeds the maximum allowable for reuse and dumping them into water bodies [9].

The great importance in assessing the quality of water for irrigation of agricultural crops is oxidizability (COD - chemical absorbed oxygen) - an indicator characterizing the total content of organic and inorganic substances in water that react with strong oxidants [7]. A high COD value $(480-850 \mathrm{mg} \mathrm{O} / \mathrm{l})$ indicates a large pollution of wastewater (maximum permissible concentration for a reservoir is $30 \mathrm{mg} / \mathrm{l}$ ) with organic products. The degree of wastewater pollution with organic matter contained in the form of non-settling suspended and colloidal particles can also be determined by the oxygen content consumed for biochemical oxidation of these substances in 1 liter of the sample during the life of aerobic bacteria. This indicator is called BOD - biochemical oxygen demand - and it varied in the discharged waters of poultry farms in the range of $0.39-0.74 \mathrm{mg} / \mathrm{l}$ (the maximum permissible concentration for a reservoir is $3 \mathrm{mg} / \mathrm{l}$ ) on the fifth day (BOD5), and in the moment of burst effluent emissions reached 1.5-1.6 $\mathrm{g} \mathrm{O}_{2} / \mathrm{l}$, ie the quality of the waste water has deteriorated almost twofold (Table 1).

Table 1. Characteristics of wastewater from poultry farms and river water to irrigate of agricultural crops

\begin{tabular}{|c|c|c|c|c|c|c|}
\hline \multirow[b]{2}{*}{ \# } & \multirow[b]{2}{*}{ Indicators } & \multirow[b]{2}{*}{ Unit } & \multicolumn{3}{|c|}{ 'Uzbekistan' poultry farm } & \multirow{2}{*}{$\begin{array}{l}\text { 'Urtachirchikp } \\
\text { arranda' } \\
\text { poultry farm }\end{array}$} \\
\hline & & & 2018 & 2019 & 2020 & \\
\hline 1 & 2 & 3 & 4 & 5 & 6 & 7 \\
\hline \multicolumn{7}{|c|}{ Wastewater from poultry farms } \\
\hline 1 & $\mathrm{pH}$ & - & 7.3 & 7.2 & 7.2 & 7.1 \\
\hline 2 & Dissolved solids & $\mathrm{mg} / \mathrm{l}$ & 430 & 650 & 720 & 580 \\
\hline 3 & COD & $\mathrm{mg} / \mathrm{l}$ & 480 & 750 & 800 & 850 \\
\hline 4 & $\mathrm{BOD}_{5}$ & $\mathrm{mg} / \mathrm{l}$ & $\frac{1,100}{390}$ & $\frac{1,500}{680}$ & $\frac{1,430}{610}$ & $\frac{1,200}{760}$ \\
\hline 5 & Total N & $\mathrm{mg} / \mathrm{l}$ & 70.7 & 61.4 & 56.5 & 66.4 \\
\hline 6 & Total P & $\mathrm{mg} / \mathrm{l}$ & 0.2 & 0.2 & 0.4 & 0.6 \\
\hline 7 & Gross K & $\mathrm{mg} / \mathrm{l}$ & 14.5 & 11.1 & 12.6 & 23.7 \\
\hline 8 & $\mathrm{Ca}$ & $\mathrm{mg} / \mathrm{l}$ & 58.5 & 50.0 & 53.5 & 69.2 \\
\hline
\end{tabular}




\begin{tabular}{|c|c|c|c|c|c|c|}
\hline 9 & $\mathrm{Mg}$ & $\mathrm{mg} / 1$ & 68.4 & 75.6 & 54.3 & 30.6 \\
\hline 10 & $\mathrm{Na}$ & $\mathrm{mg} / 1$ & 21.8 & 20.9 & 14.7 & 37.9 \\
\hline 11 & $\mathrm{Cl}$ & $\mathrm{mg} / 1$ & 16.7 & 32.8 & 22.4 & 23.6 \\
\hline 12 & $\mathrm{SO}_{4}$ & $\mathrm{mg} / 1$ & 95.4 & 99.8 & 73.2 & 78.7 \\
\hline 13 & Bicarbonates & $\mathrm{mg} / 1$ & 434.3 & 410.7 & 373.5 & 326.1 \\
\hline \multicolumn{7}{|c|}{ River water } \\
\hline 1 & $\mathrm{pH}$ & - & 7.3 & 7.5 & 7.4 & 7.3 \\
\hline 2 & Dissolved solids & $\mathrm{mg} / 1$ & 236.3 & 208.5 & 310.6 & 274.4 \\
\hline 3 & COD & $\mathrm{mg} / 1$ & 23.4 & 14.3 & 18.8 & 28.6 \\
\hline 4 & BOD 5 & $\mathrm{mg} / 1$ & $\underline{960}$ & $\underline{1,120}$ & $\underline{1.080}$ & $\underline{390}$ \\
\hline 5 & Total N & $\mathrm{mg} / 1$ & 5.9 & 4.5 & 4.0 & 5.1 \\
\hline 6 & Total P & $\mathrm{mg} / 1$ & 0.05 & 0.03 & 0.04 & 0.04 \\
\hline 7 & Gross K & $\mathrm{mg} / 1$ & 3.3 & 2.5 & 2.6 & 3.5 \\
\hline
\end{tabular}

In terms of nitrogen content, the effluents are characterized by a high fertilizing value from 51 to $87 \mathrm{mg} / \mathrm{l}$, the potassium content varied in the range of $10-32 \mathrm{mg} / \mathrm{l}$. Qualitative assessment of wastewater by the total concentration of dissolved salts, the content of chlorides, hydrocarbons, biogenic elements, toxic salts, the reaction of the medium $(\mathrm{pH})$, anionic-cationic composition and the sodium adsorption coefficient (SAR), that the wastewater of poultry farms is quite suitable for irrigating corn, cultivated for grain and silage, winter wheat, alfalfa, combined crops of alfalfa + oats, corn + soybeans + sunflower without dilution and diluted with river water in ratios of $1: 1$ and 1:2, fodder beet on meadow and sierozem soils without additional reclamation activities (Table 2).

Table 2. Suitability assessment of wastewater from poultry farms for irrigation of forage crops

\begin{tabular}{|c|c|c|c|}
\hline \multirow{2}{*}{$\#$} & \multirow{2}{*}{ Methods and approaches } & \multicolumn{2}{|c|}{ Poultry farms } \\
\hline & & Uzbekistan & Urtachirchikparranda \\
\hline 1 & $\begin{array}{c}\text { Budanov: } \\
\text { 1) } \mathrm{Na}:(\mathrm{Ca}+\mathrm{Mg}) \leq 0,7 \\
\text { 2) } \mathrm{Na}: \mathrm{Ca} \leq 1\end{array}$ & $\begin{array}{l}0.09-0.11 \\
0.24-0.37\end{array}$ & $\begin{array}{l}0.27 \\
0.48\end{array}$ \\
\hline 2 & $\begin{array}{c}\text { Mozheyko and Vorotnik: } \\
(\mathrm{K}+\mathrm{Na}) \cdot 100:(\mathrm{Ca}+\mathrm{Mg}++ \\
\mathrm{Na}) \leq 65 \%\end{array}$ & $11.87-13.47$ & 27.26 \\
\hline 3 & $\begin{array}{c}\text { US department (SAR): } \\
\mathrm{Na}: \sqrt{(\mathrm{Ca}+\mathrm{Mg})}: 2 \leq 8\end{array}$ & $0.34-0.46$ & 27.26 \\
\hline 4 & $\begin{array}{c}\text { Kelly: } \mathrm{Ca} \cdot 100:(\mathrm{Ca}++\mathrm{Mg}+ \\
\mathrm{Na}+\mathrm{K}) \geq 35 \%\end{array}$ & $24.95-32.68$ & 41.50 \\
\hline 5 & $\begin{array}{c}\text { Etone: } \\
\left(\mathrm{CO}_{3}+\mathrm{HCO}_{3}\right)-(\mathrm{Ca}+ \\
\end{array}$ & $1.5-2.1$ & 0.68 \\
\hline
\end{tabular}




\begin{tabular}{|c|c|c|c|}
\hline & $+\mathrm{Mg})<2,5$ & & \\
\hline 6 & $\begin{array}{c}\text { Stabler: }(\mathrm{K}>6) \\
\mathrm{K}=288:(\mathrm{rNa}+4 \mathrm{rCl})\end{array}$ & $61.94-100$ & 66.0 \\
\hline
\end{tabular}

In addition to the above ingredients, sewage and river water contains a large number of microorganisms, which require careful study when using water for irrigation of agricultural crops. The results of sanitary and bacteriological studies indicate that the wastewater used for irrigation of agricultural crops was significantly contaminated according to the studied indicators. So, the titer of Escherichia coli was 10-6, the number of microbes ranged from $48.5 \times 106$ to $61.6 \times 106$. At the same time, with each cubic meter of wastewater, the field received from $48.5 \times 1,012$ to $61.6 \times 1,012$ pcs microorganisms [7].

After cleaning in artificial structures, these indicators were respectively equal: the titer of E. coli - 10-4, the number of microbes in $1 \mathrm{ml}$ of water - from $40.9 \times 106$ to $52.0 \times 106$ pcs. River water was characterized by the following indicators: the number of microbes in 1 $\mathrm{ml}$ of water - from $3.7 \times 106$ to $4.5 \times 106$, and the coli-titer - 0.0004 .

Summing up, it should be noted that wastewater from poultry farms is quite suitable for irrigating agricultural crops, but the final suitability of wastewater for mineralization must be clarified in the process of constant monitoring of the accumulation of salts in the soil during the cultivation of crops.

In addition to the accumulation of salts in the soil, wastewater also has a fertilizing value, which depends on the presence of nutrients and beneficial microorganisms in them. During cleaning on artificial structures, a significant amount of nutrients is lost, when they are discharged into open water bodies, thousands of tons of fertilizers are carried away, they would play a big role in soil fertility, increasing the productivity of cultivated crops.

As a result of the intake of a large volume of nutrients and beneficial microorganisms during irrigation of land with wastewater, microbiological processes are significantly increased, as a result of which soil fertility is improved.

For irrigation of corn in our experiments, we used wastewater, requesting mechanical cleaning. During water supply, the amount of nutrients (total nitrogen, phosphorus, total potassium) was determined. The data presented in Table 1 show that the concentration of total nitrogen varied widely and ranged from 51.3 to $86.8 \mathrm{mg} / \mathrm{l}$ during the irrigation period, phosphorus was contained in insignificant amounts - $0.2-0.8 \mathrm{mg} / 1$, and potassium - $10.2-$ $31.8 \mathrm{mg} / \mathrm{l}$. Or: from every $1000 \mathrm{~m} 3$ of wastewater, $50-90 \mathrm{~kg}$ of nitrogen, about $1 \mathrm{~kg}$ of phosphorus and 10-32 kg of potassium per hectare were supplied to the field [10].

In terms of nitrogen content, the wastewaters of the Tashkent poultry farm and the poultry plant of Urtachirchikparrand, according to the classification of V.T. Dodolina (1975), refer to wastewater of average fertilizing value, and low in terms of potassium and phosphorus content [5].

These nutrients are in a dissolved and available form, getting into the soil, they are easily absorbed by plants, while simultaneously solving the problems of water and nutritional regime for corn plants. In addition, many organic substances and microorganisms enter the soil with wastewater, as a result of which microbiological processes are activated and the potential and effective soil fertility increases.

The calculations performed to determine the amount of nutrients supplied to the field with irrigation water showed that when corn was irrigated with sewage at an irrigation rate of 3,650-3,900 $\mathrm{m}^{3} / \mathrm{ha}, 179-220 \mathrm{~kg}$ of nitrogen and $42-92 \mathrm{~kg}$ of potassium were supplied per hectare of crops (taking into account the coefficient taking into account the loss of nutrients from wastewater during irrigation for nitrogen, which is 0.85 , for phosphorus and potassium - 1 [5]. With an irrigation rate of 4,400-4,650 $\mathrm{m}^{3} /$ ha, respectively, 218-264 and $51-110 \mathrm{~kg}$ for each hectare; under dilution conditions at an irrigation rate of 3,700-3,930 
$\mathrm{m}^{3} / \mathrm{ha}-98-122 \mathrm{~kg}$ of nitrogen and $16-53 \mathrm{~kg}$ of potassium, and at an irrigation rate of $4,550-4,620 \mathrm{~m}^{3} / \mathrm{ha}$ at $118-150$ and $31-63 \mathrm{~kg}$ per hectare Phosphorus was supplied with irrigation water in insignificant quantities.

The use of poultry wastewater for feeding and vegetation irrigation during the cultivation of winter wheat on gray soil contributed to the improvement of plant growth and development significantly increases the yield of grain and straw. If during feeding and vegetation irrigation with river water the grain yield averaged 45.2 quintal (q)/ha and straw $56.5 \mathrm{q} / \mathrm{ha}$ for 3 years, in the variant with feeding irrigation with river water, and vegetation irrigation with waste waters, respectively, amounted to 51.0 and $64.2 \mathrm{q} / \mathrm{ha}$. In the variant where recharge irrigation was carried out with waste water, and vegetative irrigation with river water, 3.7 quintals of grain and 7.6 quintals of straw were obtained more than in the control variant. The highest yield $-55.5 \mathrm{q} /$ ha of grain and $70.2 \mathrm{q} / \mathrm{ha}$ of straw was obtained in the variant with feeding and vegetation irrigation with waste waters. When carrying out recharge irrigation with river water, and vegetative irrigation with diluted with river wastewater and vegetative irrigation with wastewater, $40.2 \mathrm{q} / \mathrm{ha}$ of grain and $50.9 \mathrm{q} / \mathrm{ha}$ of straw were obtained, which, respectively, by 5.0 and $5.6 \mathrm{q} / \mathrm{ha}$ less than in the control variant.

Diluted from the river and undiluted waste water from poultry farms when used for irrigation in combination with mineral fertilizers on meadow soils contributed to obtaining high yields of silage mass, grain and air-dry leafy corn mass. The harvest of silage mass reached 530.6-608.3 and 564.2-641.1 q/ha, respectively, against 508.4-564.3 q/ha and grain - 77.8-82.9 and 80.6-86, 4 q/ha versus 68.6-74.6 q/ha; air dry leafy mass - 191.4-208.8 and 204.1-255.3 q/ha versus 182.3-198.4 q/ha in the control variant.

It has been established that in the hot climate of Uzbekistan, soils irrigated with wastewater become normatively clean on the 10-15th day after irrigation. With proper organization and implementation of surface irrigation with wastewater, pollution of aboveground plant organs and groundwater is completely excluded. In case of accidental contamination of individual parts of plants, they can be considered normatively clean 10-15 days after watering.

\section{Discussion and conclusion}

Our long-term studies confirm the feasibility and high efficiency of purification and disposal of wastewater in agriculture by using them for irrigation of agricultural land, especially in the arid zone of Uzbekistan. Wastewater from poultry farms is quite suitable for irrigation of forage and industrial crops without additional reclamation measures.

When irrigated with wastewater, a significant amount of nutrients enters the field, which plays a large role in providing plants and improving soil fertility. It is advisable to apply the following wastewater disposal scheme: sewerage - mechanical treatment facility - storage ponds - irrigation fields. Waste water from poultry farms is quite suitable for irrigation of forage crops used for the production of vitamin flour, haulage, silage, fodder, and forage root crops. The most acceptable option for irrigation is the use of diluted wastewater from the river in a 1: 1 ratio in combination with mineral fertilizers, since the soil self-cleaning process begins on the 15 th day after irrigation. Under the same conditions, for irrigation of alfalfa for the 2nd and 3rd years of standing with diluted sewage water from poultry factories with river water in the ratio of 1:1 or 1:2 (one part is waste and 1 or 2 parts is river water). In this case, the irrigation rate should be set according to the water demand of alfalfa. In this regard, the irrigation pattern is 1-2-2-1. One-time irrigation rate is equal to $900-1,100 \mathrm{~m}^{3} / \mathrm{ha}$. 
On meadow soils with groundwater at a level of $2-2.5 \mathrm{~m}$ of the Chirchik-Angren valley, it is advisable to use wastewater from poultry farms diluted with river water in a 1:1 ratio for irrigation of corn, cultivated as a re-crop after winter and the use of mineral fertilizers (norm $\mathrm{N}-180, \mathrm{P}_{2} \mathrm{O}_{5}-100 \mathrm{~K}_{2} \mathrm{O}-90 \mathrm{~kg} / \mathrm{ha}$ ). The timing of irrigation should be determined by the lower threshold of the moisture content of the active soil layer, $70-75-65 \%$ of the soil FWL. The irrigation rate should be in the range of 4.4-4.6 thousand $\mathrm{m}^{3} / \mathrm{ha}$, between irrigation periods of 15-20 days. Vegetation watering should be completed 15-20 days before harvest.

Irrigation and irrigation rates for cultivated crops are determined by their total water consumption, and the timing of irrigation is determined by the moisture deficit in the active soil layer. Irrigation rates for corn for silage are calculated at the lower threshold of soil moisture of $75-80 \%$ of the PPV, for corn for grain - 70-75-65\%. Irrigation rates in meadow soils should be 3.4-4.0 and 4.4-4.6 thousand $\mathrm{m}^{3} /$ ha, respectively. For fodder alfalfa of the first year of standing with four mows on meadow soils, the irrigation scheme should be 1-1$1-1$, and for alfalfa of the second year and subsequent years with five and six mows 0-1-11-1 and $0-1-1-1-1-1$ irrigation rates $1,000-1,100 \mathrm{~m}^{3} /$ ha and irrigation rates from $4.0-4.4$ to 5.0-5.5 thousand $\mathrm{m}^{3} /$ ha.

The irrigation scheme for alfalfa of the first year of standing on sierozem soils with deep groundwater should be 1-2-2-1 with irrigation rates of $900-1,100 \mathrm{~m}^{3} / \mathrm{ha}$ and irrigation rates of 5.4-6.6 thousand $\mathrm{m}^{3} / \mathrm{ha}$, and for alfalfa of the second year of standing and subsequent years - 0-1-2-2-1 with irrigation rates of 1,000-1,200 $\mathrm{m}^{3} / \mathrm{ha}$ and irrigation rates - 6.0-7.0 thousand $\mathrm{m}^{3} /$ ha.

The irrigation regime for fodder beet consists of 5 irrigations with irrigation rates of $800-1300$ thousand $\mathrm{m}^{3} /$ ha and irrigation rates of $6.0-7.0$ thousand $\mathrm{m}^{3} / \mathrm{ha}$.

In the conditions of meadow soils with a groundwater level of 1.5-1.8 m after sowing wheat, it is necessary to carry out recharge irrigation with wastewater at a rate of 700-730 $\mathrm{m}^{3} /$ ha and vegetative irrigation with wastewater diluted with river water in a ratio of 1: 1 at a rate of $700-850 \mathrm{~m}^{3} / \mathrm{ha}$ and an irrigation rate of 3,080 (including recharge irrigation $3,810) \mathrm{m}^{3} /$ ha.

Moisture-charging and fertilizing irrigation on sierozem soils should be carried out in deep furrows according to a dead-end scheme with a rate of $800-1,000 \mathrm{~m}^{3} / \mathrm{ha}$, and stop them 2-3 weeks before sowing. Control over the sanitary and hygienic state of the soil when using wastewater for irrigation is carried out on the 15th day after irrigation. When irrigating with waste water, it is necessary to comply with sanitary and anti-epidemic rules, especially in the first 20 days. When using wastewater for irrigation, the inter-irrigation periods should be at least 15-20 days in order to ensure the normal course of soil selfcleaning processes. In case of a delay in the process of self-cleaning of soils from pathogenic microorganisms, irrigation with river water should be carried out. Vegetation irrigation with waste water is completed 15-20 days before harvesting.

\section{References}

1. Presidential Decree No. 3405 of the Republic of Uzbekistan on "The state program for the development of irrigation in 2018-2019 and improvement of the reclamation state of irrigated lands" on November 27 (2017)

2. Presidential Decree No. 5853 of the Republic of Uzbekistan on "Measures for efficient use of land and water resources in agriculture" on October 23 (2019) 
3. Presidential Decree No. 6024 of the Republic of Uzbekistan about "Approval of the Concept of development of water economy of the Republic of Uzbekistan for 20202030" on June 10 (2020)

4. M. Saidan, H. J. Khasawneh, M. Tayyem, M. Hawari, Journal of Chemical Technology \& Metallurgy 56(1), 163-171 (2018)

5. Z. A. Artukmetov, Caspian Research Institute of Arid Agriculture Press, 65-70 (2017)

6. A. V. Nazarova, O. I. Sergienko, N. R. Molodkina, V. Y. Efremova, In IOP Conference Series: Earth and Environmental Science 613(1), 012088 (2020)

7. F. Zhang, Y. B. Man, W. Y. Mo, M. H. Wong, Reviews in Aquaculture 12(2), 582-599 (2020)

8. P. Song, G. Huang, C. An, X. Xin, P. Zhang, X. Chen, X. Yang, Water Research 188, 116480 (2021)

9. T. Hülsen, K. Hsieh, S. Tait, E. M. Barry, D. Puyol, D. J. Batstone, Water research 144, 665-676 (2018)

10. K. Meiramkulova, Z. Jakupova, D. Orynbekov, E. Tashenov, A. Kydyrbekova, T. Mkilima, V. J. Inglezakis, Sustainability 12(1), 5110 (2020)

11. R. Kulmatov, A. Taylakov, S. Khasanov, Envi. Science and Pollution Research, 1-11 (2021) 